\title{
Serum cholesterol levels in anorexia nervosa
}

\author{
L. M. BLENDIS* \\ M.B., M.R.C.P.
}

\author{
A. H. CRISP $\dagger$ \\ M.D., M.R.C.P.E., D.P.M.
}

Middlesex Hospital, London, W.1

IN CONTRAST to earlier investigators (Pardee, 1941 ; Stephens, 1941 ; Emmanuel, 1956) more recent workers (Crisp, 1965a, 1967 ; Oberdisse, Solbach \& Zimmerman, 1965 ; Klinefelter, 1965 ; Crisp \& Stonehill, 1967) have reported that some of their patients with anorexia nervosa have high serum cholesterol levels.

Crisp (1965a, b, 1967) in a study of eighty patients (Nos. 1-80) has also emphasized that anorexia nervosa is predominantly a state of severe chronic carbohydrate starvation having its origins in the patient's phobia of and consequent need to avoid normal adolescent weight. Such patients who will have initially turned to eating supposedly 'non-fattening' foods such as as cheese, fruit, meat and salad, may later surrender to their increasing impulse to eat carbohydrate by having binges. They may start to vomit in relation to their binges and conceal and deny one or both these aspects. Usually such binges also alternate with phases when the patient stops eating altogether. Such cycles may recur every $24 \mathrm{hr}$ or may span several weeks. These complex and often interrelating patterns of feeding make it more than usually difficult to assess the past dietary intake.

Meanwhile, a further study by Crisp et al. (1967) has confirmed that thirty-seven female patients aged 14-33 with anorexia nervosa had significantly higher serum cholesterol levels $(P<0.0002)$ than thirty-seven normal women with whom they were matched individually for age (Fig. 1). The serum cholesterol levels in the control group are the mean of two results from the two halves of the menstrual cycle. However, there was a wide variation of serum cholesterol levels amongst the anorexia nervosa group. It was confirmed that such levels bore no relationship to thyroid function or reduced plasma volume and were unlikely to be due to diminished oestrogen activity, a universal characteristic in

\footnotetext{
*Now Senior Medical Registrar, King's College Hospital, London, S.E.5.

†Now Professor of Psychiatry, St George's Hospital, London, S.W.1.
}

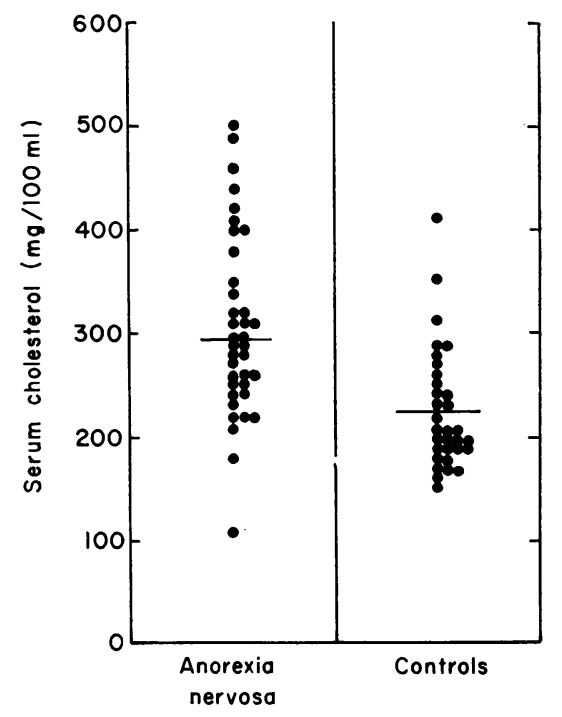

FIG. 1. Comparison of serum cholesterol levels in patients with anorexia nervosa and normal control. $P<0.0002$ (Willcoxan Matched Pairs Test-with modification for large series). Values for controls represent the mean of two estimations taken in the two halves of the menstrual cycle.

this condition. From a clinical standpoint high levels were not found to be related to age, duration of illness or prognosis. However, there appeared to be a relationship between particularly high serum cholesterol levels and the feeding pattern of intermittent bulimia involving ingestion of large quantities of carbohydrate and fat interspersed with phases of abstinence. A further investigation was therefore aimed at the study of serum cholesterol levels in relation to controlled dietary intake. The results of this study are reported below.

\section{Patients and method}

The last eight consecutive patients with anorexia nervosa admitted to this hospital were studied. Five patients were characterized by intermittent bulimia preceding their admission 
TABLE 1

Changes in serum cholesterol levels in patients with anorexia nervosa during feeding

\begin{tabular}{|c|c|c|c|c|c|c|c|}
\hline \multirow[b]{2}{*}{$\begin{array}{l}\text { Patient } \\
\text { No. }\end{array}$} & \multirow[b]{2}{*}{ Age } & \multicolumn{3}{|c|}{ Serum cholesterol $(\mathrm{mg} / 100 \mathrm{ml})$} & \multicolumn{2}{|c|}{ Weight (kg) } & \multirow{2}{*}{$\begin{array}{c}\text { Gain in } \\
\text { weight } \\
\text { (kg) }\end{array}$} \\
\hline & & $\begin{array}{c}\text { Before } \\
\text { treatment }\end{array}$ & $\begin{array}{c}\text { After } \\
\text { treatment }\end{array}$ & $\begin{array}{l}\text { Change in } \\
\text { cholesterol }\end{array}$ & $\begin{array}{c}\text { Before } \\
\text { treatment }\end{array}$ & $\begin{array}{c}\text { After } \\
\text { treatment }\end{array}$ & \\
\hline \multicolumn{8}{|l|}{ Group 1} \\
\hline 23 & 19 & 350 & 220 & -130 & 37 & 46 & 9 \\
\hline 27 & 19 & 480 & 280 & -200 & 39 & 55 & 16 \\
\hline 38 & 23 & 430 & 350 & -80 & 55 & 64 & 9 \\
\hline 6 & 13 & 260 & 160 & -100 & 32 & 52 & 20 \\
\hline 76 & 19 & 290 & 290 & -0 & 37 & 47 & 10 \\
\hline \multicolumn{8}{|l|}{ GROUP 2} \\
\hline 70 & 27 & 220 & 340 & +120 & 32 & 55 & 23 \\
\hline 75 & 22 & 230 & 350 & +120 & 38 & 48 & 10 \\
\hline 77 & 19 & 220 & 280 & +60 & 31 & 45 & 14 \\
\hline
\end{tabular}

(Group 1) although one of these (No. 76) in addition had long periods of total abstinence. The other three patients had persistently severely restricted their carbohydrate intake over a period of many months prior to admission. All of the patients were strikingly underweight, except one (No. 38) and all were suffering from amenorrhoea. Serial serum cholesterol levels were examined in these patients, by the method of Zurbowski (1964), in relation to their treatment programme. This involved the restoration of their weight to within normal limits by means of a balanced diet of the order of 2000-3000 calories daily and chlorpromazine in a dose of $500-800 \mathrm{mg}$ daily as previously described by Crisp (1966).

\section{Results}

Table 1 shows the serum cholesterol levels before and after refeeding in the two groups. Fig. 2 provides an example of the pattern of change in weight and serum cholesterol level seen in

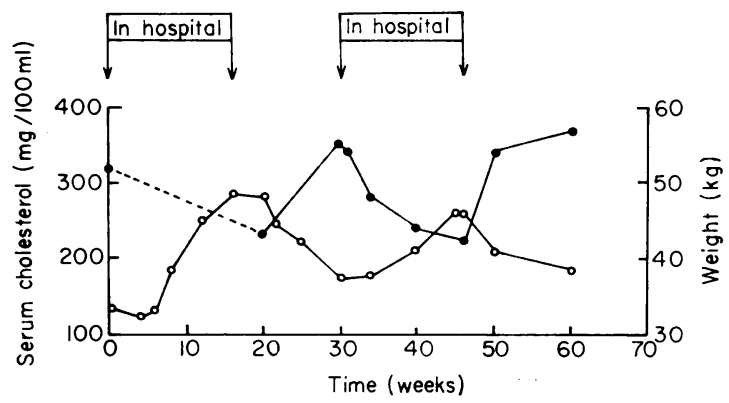

Fig. 2. The relationship of serum cholesterol to body weight (O): an example of the 'reciprocal' relationship. - - , Serum cholesterol;..- , serum cholesterol without serial observations. Patient No. 23. four of the five patterns in Group 1. On her two admissions to hospital with severe weight loss the patient had serum cholesterol levels of over $300 \mathrm{mg} / 100 \mathrm{ml}$ which fell to within normal limits on refeeding. During two periods of relapse with weight loss the serum cholesterol steadily rose. This illustrates a 'reciprocal' relationship.

Fig. 3 provides an example of patients in

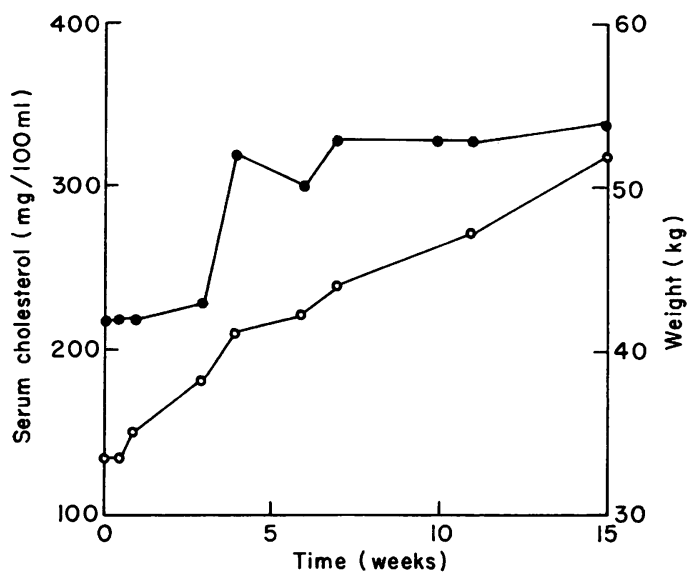

Fig. 3. The relationship of serum cholesterol (O) to body weight $(\mathrm{O})$ : an example of the 'parallel' relationship. Patient No. 70.

Group 2 in which serum cholesterol levels gradually rise to above normal levels during the refeeding period and therefore show a 'parallel' relationship to changes in body weight. Fig. 4 shows the relationship of serum cholesterol levels to increase in body weight in patient No. 76, the patient with a mixed feeding pattern prior 
to admission. It would seem that she shows an 'intermediate' pattern.

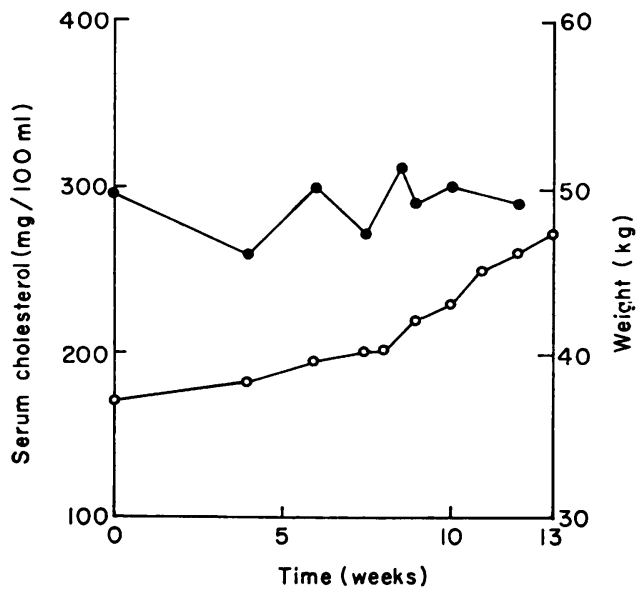

FIG. 4. The relationship of serum cholesterol (O) to body weight $(O)$ : an example of an 'intermediate' relationship. Patient No. 76.

\section{Discussion}

Evidence so far suggests that anorexia nervosa patients with high serum cholesterol levels may owe this, at least in part, to their feeding pattern of intermittent bulimia with or without vomiting. When these patients are treated by refeeding the serum cholesterol levels tend to fall. In contrast, patients with low or normal serum cholesterol levels tend to be characterized by eating small, regular, low carbohydrate meals and their serum cholesterol levels tend to rise during refeeding. In addition there would appear to be an intermediate group who have a mixed feeding pattern with periods of bulimia interspersed amongst long periods of abstinence as characterized by patient No. 76. It may be that when a larger number of patients with this condition are studied this intermediate group will prove to be more common.

The above findings are not dissimilar to those of Fabry et al. (1964) who showed a similar relationship between serum cholesterol levels and frequency of eating in a male obese population, although the feeding patterns were not so extreme or bizarre as in our group of patients. Our results are also in agreement with other authors who have shown that animals forcibly fed with large occasional meals have raised lipid levels as compared to animals who nibble normally but have the same calorie intake (Cohn,
1961 ; Hollifield \& Parson, 1962; Tepperman \& Tepperman, 1964). Gwinup et al. (1963) and Cohn (1964), comparing frequent and infrequent experimental dietary patterns in humans, have produced similar results.

Chlorpromazine has been shown to have a variable effect on cholesterol and lipid metabolism. Kai (1961) found a decrease in cholesterol levels in patients suffering from schizophrenia treated with chlorpromazine whilst Hollister \& Kanter (1955) did not find any consistent change in elderly people. Since all eight patients received this drug in comparable amounts it is unlikely to have produced the differences in cholesterol levels described here.

The significance of the different patterns of change in serum cholesterol levels during refeeding remains a problem. Further investigation into dietary content and patterns of eating in anorexia nervosa and their effect on cholesterol and other parameters of fat metabolism both before and during treatment is now in progress.

\section{Acknowledgments}

We are grateful to The Courtauld Institute of Biochemistry for performing the cholesterol estimations and to Professor Sir Denis Hill, Dr G. D. Hadley and Dr P. A. J. Ball for allowing us to study patients under their care.

\section{References}

CoHN, C. (1961) Meal eating, nibbling and body metabolism. J. Amer. Diet. Ass. 38, 433.

CoHN, C. (1964) Feeding patterns and some aspects of cholesterol metabolism. Fed. Proc. 23, 76.

CrisP, A.H. (1965a) Clinical and therapeutic aspects of anorexia mervosa-A study of 30 cases. J. psychosom. Res. 9, 67.

CrisP, A.H. (1965b) Some aspect of the evolution, presentation and follow up of anorexia nervosa. Proc. roy. Soc. Med. 58, 814.

CrisP, A.H. (1966) A treatment regime for anorexia nervosa. Brit. J. Psychiat. 112, 505.

CRISP, A.H. (1967) Anorexia nervosa. Hosp. Med. 1, 713.

Crisp, A.H., Blendis, L.M., Pawan, G.L.S. \& LACE, A. (1967) Some aspects of fat metabolism in anorexia nervosa. Proc. Nutr. Soc. 26, 32.

CrisP, A.H. \& Stonehill, E. (1967) Hypercarotenaemia as a symptom of weight phobia. Postgrad. med. J. 43, 721 .

EMmANUEL, R.W. (1956) Endocrine activity in anorexia nervosa. J. clin. Endocrin. 16, 801.

FABry, P., Fodor, J., HeJl, Z., Braun, T. \& ZvolánKová, K. (1964) The frequency of meals; its relation to overweight hypercholesterolaemia and decreased glucose tolerance. Lancet, ii, 614.

Gwinup, G., Byron, R., Roush, W., Weissler, A., Kruger, F. \& HAMWI, G. (1963) The effect of gnawing and nibbling on serum lipid levels. Clin. Res. 11, 219.

Hollifield, G. \& Parson, W. (1962) Metabolic adaptations to a 'stuff and starve' feeding program. J. clin. Invest. $41,250$.

Hollister, L.E. \& KanTer, S.L. (1955) Essential hyperlipaemia treated with heparin and with chlorpromazine. Gastroenterlogy, 29, 1069. 
KAI, J (1961) Effect of chlorpromazine on the level of lipids, lipoproteins and proteins and on the activity of lipoprotein lipase in blood serum in man Psychopharm Abstr. $1,542$.

KLinefelter, H.F. (1965) Hypercholesterolaemia in anorexia nervosa. J. clin. Endocrin. 25, 1520.

Oberdisse, K., Solbach, H.G. \& Zimmerman, H. (1965) Anorexia Nervosa, Gottingen Symposium (Ed. by J. E. Meyer and H. Feldmann), p. 26. Thieme, Stuttgart.
Pardee, I. (1941) Cachexia (anorexia nervosa). Med. Clin. N. Amer. 25, 755.

Stephens, D.J. (1941) Anorexia nervosa: endocrine factors in undernutrition. J. clin. Endocrin. 1, 257.

Tepperman, H.M. \& Tepperman, J. (1964) Adaptive hyperlipogenesis. Fed. Proc. 23, 73.

ZurbowsKi, P. (1964) A rapid method for cholesterol determination with a single reagent. Clin. Chem. 10, 451. 